\title{
New Cytotoxic Cytochalasans from a Plant-Associated Fungus Chaetomium globosum kz-19
}

\author{
Tantan Li ${ }^{1,2}$, Yun Wang ${ }^{1}$, Li Li ${ }^{4}\left(\mathbb{D}\right.$, Mengyue Tang ${ }^{1,3}$, Qinghong Meng ${ }^{1,2}$, Cun Zhang ${ }^{1}$, Erbing Hua ${ }^{2, *}$, \\ Yuehu Pei ${ }^{3, *}$ and Yi Sun $1, *$ (D)
}

1 Institute of Chinese Materia Medica, China Academy of Chinese Medical Sciences, Beijing 100700, China; tantanna0309@163.com (T.L.); ywang@icmm.ac.cn (Y.W.); lotusun69@163.com (M.T.); qinghongmeng0813@hotmail.com (Q.M.); czhang@icmm.ac.cn (C.Z.)

2 College of Biotechnology, Tianjin University of Science \& Technology, Tianjin 300457, China

3 School of Pharmacy, Harbin Medical University, Harbin 150081, China

4 Institute of Materia Medica, Chinese Academy of Medical Sciences \& Peking Union Medical College, Beijing 100050, China; annaleelin@imm.ac.cn

* Correspondence: huarb@tust.edu.cn (E.H.); peiyueh@vip.163.com (Y.P.); ysun@icmm.ac.cn (Y.S.); Tel.: +86-10-6403-2656 (Y.S.)

check for

updates

Citation: Li, T.; Wang, Y.; Li, L.; Tang, M.; Meng, Q.; Zhang, C.; Hua, E.; Pei, Y.; Sun, Y. New Cytotoxic Cytochalasans from a Plant-Associated Fungus Chaetomium globosum kz-19. Mar. Drugs 2021, 19, 438. https://doi.org/10.3390/ md19080438

Academic Editor:

Giuseppina Chianese

Received: 12 July 2021

Accepted: 28 July 2021

Published: 31 July 2021

Publisher's Note: MDPI stays neutral with regard to jurisdictional claims in published maps and institutional affiliations.

Copyright: (C) 2021 by the authors Licensee MDPI, Basel, Switzerland. This article is an open access article distributed under the terms and conditions of the Creative Commons Attribution (CC BY) license (https:/ / creativecommons.org/licenses/by/ $4.0 /)$.

\begin{abstract}
Four new cytochalasans, phychaetoglobins A-D (1-4), together with twelve known cytochalasans (5-16), were isolated from a mangrove-associated fungus Chaetomium globosum kz-19. The new structures were elucidated on the basis of extensive 1D and 2D NMR, HR ESIMS spectroscopic analyses, and electronic circular dichroism (ECD) calculations. The absolute configuration of 2 was established by application of Mosher's method. Compounds 4-8 exhibited moderate cytotoxicities against $\mathrm{A} 549$ and HeLa cell lines with the $\mathrm{IC}_{50}$ values less than $20 \mu \mathrm{M}$.
\end{abstract}

Keywords: Chaetomium globosum kz-19; endophytic fungus; cytochalasans; cytotoxicity

\section{Introduction}

Natural products from plant-associated fungi are a rich source of biologically promising lead compounds. The fungus genus Chaetomium is the rich source of cytochalasans, among which Chaetomium globosum can produce plenty of such secondary metabolites [1-5]. As the main secondary metabolites from $C$. globosum, cytochalasans are a class of compounds containing isoindolinone moieties fused to the tricyclic or tetracyclic ring systems, which have a variety of pharmacological activities, such as antitumor [6], antibacterial [7], immunomodulatory [8], and phytotoxicity [9]. The polyketo-amino acid hybrid structure of cytochalasans forms different fused macrocycles (typical 11- or 13-membered macrocycles) of cytochalasans, such as macrocycle, polycyclic, helix, epoxide, hydrogen peroxide groups and other unique structures. Biogenetically, cytochalasans are biosynthesized through a hybrid pathway of polyketide synthase (PKS) and non-ribosomal peptide synthetase (NRPS). The che cluster in Penicillium expansum was recognized as the first gene cluster encoding PKS-NRPS in the biosynthesis of cytochalasans [10]. In addition, the oxidative tailoring enzymes of CcsB and CHGG_012343 catalyzed multiple steps involved in the process of biosynthesis [11]. In terms of anti-tumor pharmacological effects, many researchers found that cytochalasans could regulate the morphology and phenotype of tumor cells and induce apoptosis [12]. Thus, cytochalasans have the potential to be used as a supplementary chemotherapeutic drug and to decrease the incidence of drug resistance clinically in the future [13].

In our continuous research on antitumor secondary metabolites from endophytic microorganisms [14], we used the bioassay method to screen fungi. During the screening process, we found an endophytic fungus Chaetomium globosum kz-19, which was isolated from the mangrove plant, Ceriops tagal. Its EtOAc extract of rice cultures exhibited strong cytotoxicity against HeLa cell lines $\left(\mathrm{IC}_{50}=11.0 \mu \mathrm{g} / \mathrm{mL}\right)$. A large-scale 
solid culture followed by repeated chromatographic isolation led to the identification of four new cytochalasans phychaetoglobins A-D (1-4), together with twelve known cytochalasans, chaetoglobosin C (5) [15], chaetoglobosin E (6) [15], chaetoglobosin G (7) [16], chaetoglobosin V (8) [17], chaetoglobosin Fex (9) [4], isochaetoglobosin D (10) [4], chaetoglobosin J (11) [15,18], armochaetoglobosin G (12) [5], penochalasin G (13) [19], penochalasin $\mathrm{J}$ (14) [20], prochaetoglobosin $\mathrm{III}_{\mathrm{ed}}$ (15) [21], and chaetoglobosin D (16) [15,18] (Figure 1).
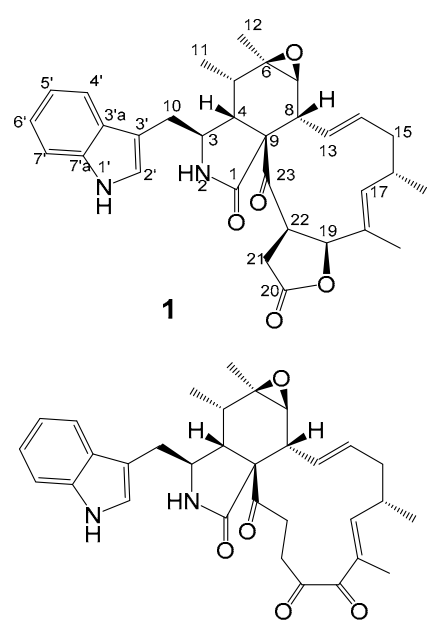

5

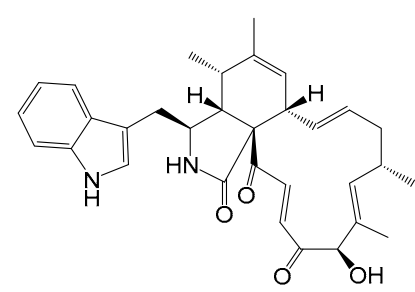

11

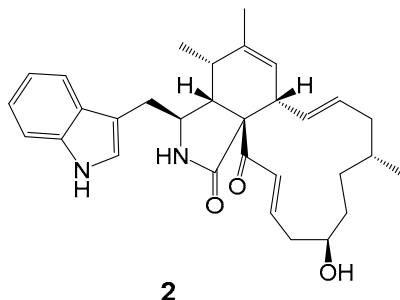

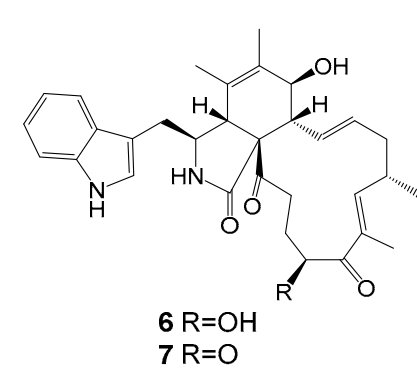

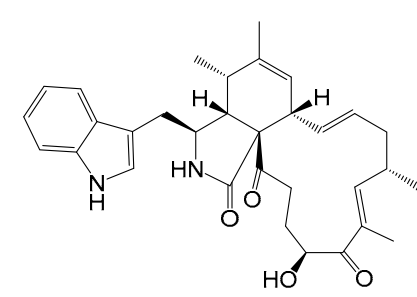

12

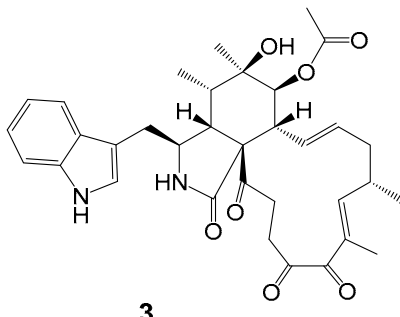

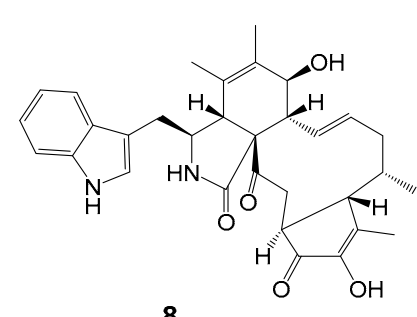

8

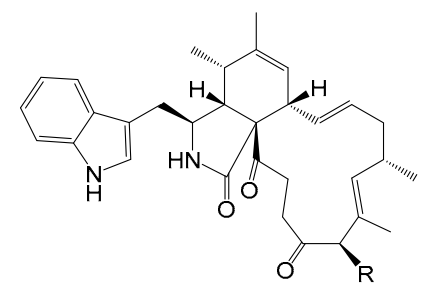

$13 \mathrm{R}=\mathrm{OH}$ $14 \mathrm{R}=\mathrm{H}$

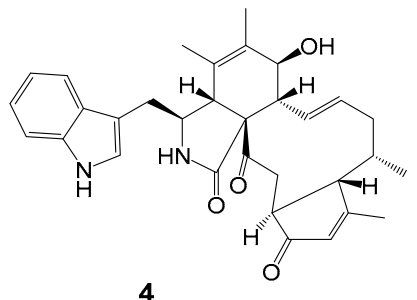

4

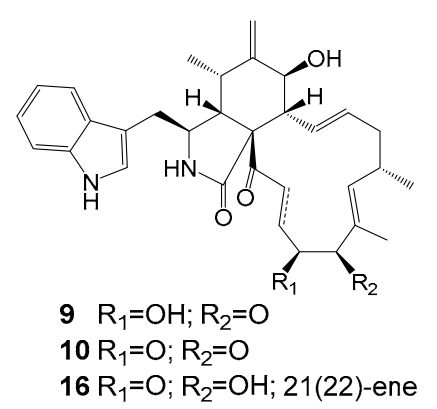

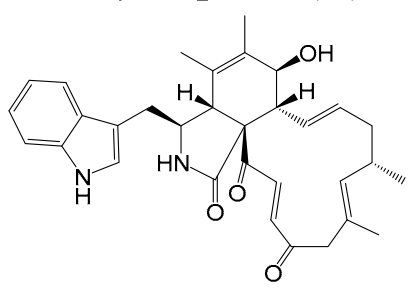

15

Figure 1. Chemical structures of compounds 1-16.

\section{Results and Discussion}

\subsection{Structure Elucidation}

Compound $\mathbf{1}$ was obtained as a pale yellow solid. Its molecular formula was deduced as $\mathrm{C}_{32} \mathrm{H}_{36} \mathrm{~N}_{2} \mathrm{O}_{5}$ by HR ESIMS and NMR data, indicating 16 degrees of unsaturation. Analysis of the ${ }^{1} \mathrm{H}-\mathrm{NMR}$ spectrum of $\mathbf{1}$ (Table 1) suggested the presence of two amide protons at $\delta_{\mathrm{H}} 11.11(\mathrm{~d}, 1.4 \mathrm{~Hz})$ and $8.52(\mathrm{~s})$, five aromatic protons at $\delta_{\mathrm{H}} 7.56(\mathrm{~d}, 7.7 \mathrm{~Hz})$, $7.29(\mathrm{~d}, 7.9 \mathrm{~Hz}), 7.26(\mathrm{~d}, 2.2 \mathrm{~Hz}), 7.14(\mathrm{t}, 7.2 \mathrm{~Hz})$ and $7.02(\mathrm{t}, 7.2 \mathrm{~Hz})$, three olefinic protons at $\delta_{\mathrm{H}} 5.43(\mathrm{dd}, 15.2,10.4 \mathrm{~Hz}), 5.13(\mathrm{~d}, 11.1 \mathrm{~Hz})$ and $4.78(\mathrm{td}, 15.0,3.6 \mathrm{~Hz})$, two methyl singlets $\left(\delta_{\mathrm{H}} 1.23\right.$ and 1.29), and two methyl doublets at $\delta_{\mathrm{H}} 0.88(\mathrm{~d}, 6.5 \mathrm{~Hz})$ and $0.99(\mathrm{~d}$, $7.4 \mathrm{~Hz}$ ). Determination of the ${ }^{13} \mathrm{C}$ NMR combined with the ${ }^{1} \mathrm{H}$ NMR spectra of $\mathbf{1}$ (Table 2) revealed the presence of three carbonyl groups $\left(\delta_{\mathrm{C}} 204.7,175.0\right.$, and 172.8$)$, a 3-substituted indolyl group $\left(\delta_{\mathrm{C}} 108.0,111.7,118.2,118.9,121.1,125.8,127.8,136.1\right)$, and three oxygenated groups $\left(\delta_{C} 84.9,59.9,56.7\right)$, which had the characteristic skeleton of cytochalasans closely resembling chaetoglobosin $\mathrm{C}(5)$. Further analyses of ${ }^{1} \mathrm{H}$ and ${ }^{13} \mathrm{C} N M R$, as well as the 2D NMR spectra of $\mathbf{1}$ (Figure 2a), supported the presence of an indolyl moiety, a pyrrolidine2 -one, and a cyclohexane ring in the structure, as was the case with that of 5. However, the differences between $\mathbf{1}$ and $\mathbf{5}$ were that $\mathbf{1}$ possessed two fewer ketone groups and one more ester group than 5. The HMBC correlations from H-19 to C-17, C-18, and C-20, as well as from $\mathrm{H}-21$ to $\mathrm{C}-20, \mathrm{C}-22$, and C-23, revealed the presence of a lactone ring. Further 
HMBC correlations from H-8 to C-9, C-13, C-14, and C-23, as well as from $18-\mathrm{CH}_{3}$ to $\mathrm{C}-17, \mathrm{C}-18$, and C-19, indicated the presence of two olefinic bonds and a ketone group on the macrocycle. The relative configuration of $\mathbf{1}$ was determined by a NOESY spectrum (Figure $2 \mathrm{~b}$ ) and proton-proton coupling constants. A large coupling constant $(J=15.2 \mathrm{~Hz})$ observed between $\mathrm{H}-13$ and $\mathrm{H}-14$ indicated the $E$-geometry of $\Delta^{13}$-double bond. Additional coupling constants $(J=10.4,5.2 \mathrm{~Hz})$ of $\mathrm{H}-8$ with $\mathrm{H}-13$ and $\mathrm{H}-7$ in the ${ }^{1} \mathrm{H}$ NMR spectrum revealed that $\mathrm{H}-8$ was orientated axial, and the NOESY cross-peaks of $\mathrm{H}-8$ with $\mathrm{H}-4$ and $\mathrm{H}-5$ further confirmed the twist-boat conformation of the cyclohexane ring. The observed NOESY cross-peaks of $\mathrm{H}-15 \alpha$ with $\mathrm{H}-13$ and $\mathrm{H}-17, \mathrm{CH}_{3}-18$ with $\mathrm{H}-16$, as well as $\mathrm{H}-17$ with $\mathrm{CH}_{3}-16$, implied an $\alpha$-orientation at $\mathrm{CH}_{3}-16$ and the E-geometry of $\Delta^{17}$-double bond. Consequently, the NOESY cross-peaks of $\mathrm{H}-3$ with $\mathrm{CH}_{3}-11$, and $\mathrm{CH}_{3}-12$ with $\mathrm{H}-7$, suggested that they were cofacial and in the $\alpha$-orientation. Additionally, the NOESY correlations of $\mathrm{H}-22$ with $\mathrm{H}-19$ and $\mathrm{H}-21 \alpha$, together with the coupling constant $(J=8.8 \mathrm{~Hz})$ between $\mathrm{H}-19$ and $\mathrm{H}-22$, revealed the $\beta$-orientation of the five-numbered lactone ring. To determine the absolute configuration of $\mathbf{1}$, the theoretically calculated electronic circular dichroism (ECD) spectra were performed using time-dependent density functional theory (TDDFT). The Merck Molecular Force Field (MMFF) conformational search in an energy window of $10 \mathrm{kcal} / \mathrm{mol}$, which was optimized at the $\omega \mathrm{B} 97 \mathrm{X} / \mathrm{TXVP}$ level (in MeOH), yielded two lowenergy geometries with a Boltzmann population of over 1\% (Figure S9). The configurations of $1 \mathbf{a}$ and $\mathbf{1 b}(\mathbf{1 b}$ was the enantiomer of $\mathbf{1 a})$ were compared using the ECD calculation at B3LYP level (Figure S9). The experimental ECD curve of 1 was in agreement with the computed curve of $\mathbf{1 a}$ (Figure 2c). Therefore, the absolute structure of $\mathbf{1}$ was finally established as $3 S, 4 R, 5 S, 6 R, 7 S, 8 R, 9 S, 16 S, 19 S, 22 R$ and named phychaetoglobin A.

Compound 2 was obtained as a colorless solid, and the molecular formula was determined to be $\mathrm{C}_{31} \mathrm{H}_{38} \mathrm{~N}_{2} \mathrm{O}_{3}$ based on the HRESIMS. A comparison of the ${ }^{1} \mathrm{H}$ and ${ }^{13} \mathrm{C}$ NMR spectra for 2 (Tables 1 and 2) with those of penochalasin J (14) suggested that 2 had a similar skeleton to 14. However, the signals for a double bond at C-17/C-18, a methyl at C-18, and a ketone group at $\mathrm{C}-20$ in $\mathbf{1 4}$ were missing in the NMR spectra of $\mathbf{2}$. The information was supported by the $\mathrm{HMBC}$ correlations from $\mathrm{CH}_{3}-16$ to $\mathrm{C}-15, \mathrm{C}-16$ and $\mathrm{C}-17$, and from $\mathrm{H}-18$ to C-17, C-19, and C-20, as well as by the ${ }^{1} \mathrm{H}^{-1} \mathrm{H}$ COSY spin system from $\mathrm{H}-16$ to $\mathrm{H}-22$. These correlations revealed the presence of three methylenes and a methine connected with a hydroxyl group at $\mathrm{C}-19$. Further HMBC correlations from a pair of olefinic protons, $\mathrm{H}-21 / \mathrm{H}-22$ to $\mathrm{C}-20$ and $\mathrm{C}-23$, also indicated the presence of an $\alpha, \beta$-unsaturated ketone moiety at C-21, C-22, and C-23. The above observations confirmed the planar structure of 2 . The relative configuration of $\mathbf{2}$ was deduced by a NOESY analysis, which was similar to that of 1 . The NOESY cross-peaks of H-4/H-8/Me-11 inferred that they had the same $\beta$-orientations at these positions as 1 . Moreover, Me-16 showed NOESY correlations with $\mathrm{H}-18$ and $\mathrm{H}-14$, which indicated the $\alpha$-orientation of Me-16. The absolute configuration of C-19 was identified by the modified Mosher's method (Figure 3). The methyl ester alcohol of 2 was treated with $R-(-)$ - and $S-(+)-\alpha$-methyoxy- $\alpha$-(trifluoromethyl) phenyl acetyl chloride (MTPA-Cl) to afford the $S$ - and $R$-MTPA esters (2c and $2 \mathrm{~d}$ ), respectively. Analysis of the ${ }^{1} \mathrm{H}$ NMR and ${ }^{1} \mathrm{H}-{ }^{1} \mathrm{H}$ COSY spectra led to the assignment of both esters' chemical shifts in proximity at $C-19$. The results of $\Delta \delta_{S-R}$ values confirmed that the absolute configuration of C-19 was $R$ (Figure 3). In addition, the ECD spectrum of 2 was determined and the Cotton effects were identical with the calculated curve of the enantiomer $2 a$ (Figure $2 c$ and Figure S18). Thus, compound 2 was identified and named phychaetoglobin B (Figure 1).

Table 1. ${ }^{1} \mathrm{H}$ NMR Data for Compounds 1--4 recorded in DMSO-d6 (600 MHz, J in Hz).

\begin{tabular}{ccccc}
\hline Position & $\mathbf{1}$ & $\mathbf{2}$ & $\mathbf{3}$ & $\mathbf{4}$ \\
\hline $2-\mathrm{NH}$ & $8.52, \mathrm{~s}$ & $7.86, \mathrm{~s}$ & $8.50, \mathrm{~s}$ & $8.21, \mathrm{~s}$ \\
3 & $3.84, \mathrm{dd}(8.6,4.3)$ & $3.66, \mathrm{dd}(8.5,4.2)$ & $3.72, \mathrm{dd}(8.5,4.2)$ & $3.36, \mathrm{~m}$ \\
4 & $1.90, \mathrm{~m}$ & $2.83, \mathrm{~m}$ & $2.14, \mathrm{~m}$ & $2.95, \mathrm{brs}$ \\
5 & $1.47, \mathrm{~m}$ & $2.20, \mathrm{~m}$ & $1.90, \mathrm{~m}$ & \\
\hline
\end{tabular}


Table 1. Cont.

\begin{tabular}{|c|c|c|c|c|}
\hline Position & 1 & 2 & 3 & 4 \\
\hline 7 & $2.83, \mathrm{~d}(5.2)$ & $5.24, \mathrm{~s}$ & $4.47, \mathrm{~d}(12.2)$ & $3.85, \mathrm{~d}(9.7)$ \\
\hline 8 & $2.61, \mathrm{dd}(10.4,5.2)$ & $2.61, \mathrm{~m}$ & $2.91, \mathrm{dd}(12.2,10.2)$ & $2.12, \mathrm{t}(10.4)$ \\
\hline 10 & $\begin{array}{c}\text { 2.87, dd }(15.0,3.6) ; 2.95 \\
\text { dd }(15.0,5.0)\end{array}$ & $\begin{array}{c}\text { 2.57, dd }(14.3,6.6) ; 2.68 \\
\text { dd }(14.3,4.9)\end{array}$ & $\begin{array}{c}2.93, \mathrm{~m} \\
2.69, \mathrm{dd}(15.0,3.8)\end{array}$ & $\begin{array}{l}2.73, \text { dd }(14.0,5.4) \\
2.28, \mathrm{~m}\end{array}$ \\
\hline 11 & $0.99, \mathrm{~d}(7.4)$ & $0.76, \mathrm{~d}(7.3)$ & $0.98, \mathrm{~d}(7.0)$ & $1.08, \mathrm{~s}$ \\
\hline 12 & $1.29, \mathrm{~s}$ & $1.62, \mathrm{~s}$ & $1.03, \mathrm{~s}$ & $1.51, \mathrm{~s}$ \\
\hline 13 & $5.43, \mathrm{dd}(15.2,10.4)$ & 6.15, dd $(15.0,9.5)$ & 5.53, dd $(14.9,9.5)$ & 5.17 , dd $(14.9,10.0)$ \\
\hline 14 & 4.78, ddd $(15.2,11.2,3.6)$ & $5.12, \operatorname{ddd}(15.0,10.6,2.9)$ & 4.86 ddd $(15.0,11.2,2.8)$ & 6.25, dd $(14.9,10.6)$ \\
\hline & $1.54, \mathrm{dd}(11.8,11.6)$ & $1.62, \mathrm{~m}$ & $2.25, \mathrm{~m}$ & $2.53, \mathrm{~m}$ \\
\hline 15 & $2.19, \mathrm{~m}$ & $2.00, \mathrm{~m}$ & $1.67, \mathrm{~m}$ & $1.76, \mathrm{dd}(13.3,11.5)$ \\
\hline 16 & $2.32, \mathrm{~m}$ & $2.19, \mathrm{~m}$ & $2.64, \mathrm{~m}$ & $2.37, \mathrm{~m}$ \\
\hline $16-\mathrm{CH}_{3}$ & $0.88, \mathrm{~d}(6.5)$ & $0.86, d(6.7)$ & $0.92, \mathrm{~d}(6.7)$ & $0.67, \mathrm{~d}(6.8)$ \\
\hline 17 & $5.13, \mathrm{~d}(11.1)$ & $\begin{array}{l}1.28, \mathrm{~m} \\
0.80, \mathrm{~m}\end{array}$ & 5.85, dd $(10.1,1.3)$ & 2.95, brs \\
\hline 18 & -- & $\begin{array}{l}1.38, \mathrm{~m} \\
1.10, \mathrm{~m}\end{array}$ & -- & -- \\
\hline $18-\mathrm{CH}_{3}$ & $1.23, \mathrm{~s}$ & - & $1.70, \mathrm{~s}$ & $2.09, \mathrm{~s}$ \\
\hline 19 & $4.84, \mathrm{~d}(8.8)$ & $3.65, \mathrm{~m}$ & -- & $5.59, \mathrm{~s}$ \\
\hline 20 & -- & $\begin{array}{l}2.29, \mathrm{~m} \\
2.20, \mathrm{~m}\end{array}$ & -- & -- \\
\hline 21 & $2.46, \mathrm{~m}$ & 6.69, ddd $(15.9,9.8,5.5)$ & $\begin{array}{l}2.35, \mathrm{~m} \\
1.74, \mathrm{~m}\end{array}$ & $2.43, \mathrm{~m}$ \\
\hline 22 & $2.66, \mathrm{~m}$ & $6.85, \mathrm{~d}(15.9)$ & $2.45, \mathrm{~m}$ & $\begin{array}{l}3.54, \mathrm{~m} \\
2.45, \mathrm{~m}\end{array}$ \\
\hline 25 & -- & -- & $1.90, \mathrm{~s}$ & -- \\
\hline $1^{\prime}-\mathrm{NH}$ & $11.1, \mathrm{~s}$ & $10.8, \mathrm{~s}$ & $11.0, \mathrm{~s}$ & $10.9, \mathrm{~s}$ \\
\hline $2^{\prime}$ & $7.26, \mathrm{~d}(2.2)$ & $7.04, \mathrm{~s}$ & $7.17, \mathrm{~d}(1.8)$ & $7.02, \mathrm{~s}$ \\
\hline $4^{\prime}$ & $7.56, \mathrm{~d}(7.7)$ & $7.45, \mathrm{~d}(8.0)$ & $7.54, \mathrm{~d}(7.8)$ & $7.43, \mathrm{~d}(7.9)$ \\
\hline $5^{\prime}$ & $7.02, \mathrm{~m}$ & $6.95, \mathrm{~m}$ & $7.00, \mathrm{~m}$ & $6.96, \mathrm{~m}$ \\
\hline $6^{\prime}$ & $7.14, \mathrm{~m}$ & $7.03, \mathrm{~m}$ & $7.07, \mathrm{~m}$ & $7.06, \mathrm{~m}$ \\
\hline $7^{\prime}$ & $7.29, \mathrm{~d}(7.9)$ & $7.29, \mathrm{~d}(8.1)$ & $7.34, \mathrm{~d}(7.8)$ & $7.33, \mathrm{~d}(8.1)$ \\
\hline
\end{tabular}

Table 2. ${ }^{13} \mathrm{C}$ NMR Data for Compounds 1--4 recorded in DMSO-d6 (150 MHz).

\begin{tabular}{ccccc}
\hline Position & $\mathbf{1}$ & $\mathbf{2}$ & $\mathbf{3}$ & $\mathbf{4}$ \\
\hline 1 & 172.8 & 174.0 & 173.4 & 174.0 \\
3 & 53.0 & 53.3 & 52.3 & 57.1 \\
4 & 48.2 & 48.5 & 43.7 & 48.7 \\
5 & 35.3 & 34.5 & 39.2 & 125.7 \\
6 & 56.7 & 139.8 & 71.9 & 133.8 \\
7 & 59.9 & 126.3 & 73.0 & 67.8 \\
8 & 44.7 & 47.3 & 43.3 & 53.6 \\
9 & 65.8 & 66.4 & 62.1 & 31.0 \\
10 & 31.9 & 33.5 & 31.2 & 17.0 \\
11 & 13.9 & 13.3 & 12.9 & 14.5 \\
12 & 20.1 & 19.8 & 24.3 & 131.4 \\
13 & 130.1 & 130.3 & 125.8 & 132.1 \\
14 & 130.9 & 132.4 & 133.3 & 38.1 \\
15 & 40.4 & 41.4 & 40.1 & 15.0 \\
16 & 31.5 & 33.8 & 32.2 & 47.6 \\
$16-\mathrm{CH}_{3}$ & 20.2 & 22.4 & 19.2 & 180.5 \\
17 & 137.8 & 29.6 & 154.8 & 17.2 \\
18 & 129.0 & 34.8 & 131.0 & 128.5 \\
$18-\mathrm{CH} \mathrm{H}_{3}$ & 11.4 & -- & 10.4 & 207.0 \\
19 & 84.9 & 69.2 & 195.8 & \\
20 & 175.0 & 39.4 & 204.9 & \\
\hline
\end{tabular}


Table 2. Cont.

\begin{tabular}{ccccc}
\hline Position & $\mathbf{1}$ & $\mathbf{2}$ & $\mathbf{3}$ & $\mathbf{4}$ \\
\hline 21 & 31.5 & 142.8 & 32.7 & 42.6 \\
22 & 49.3 & 129.3 & 35.9 & 40.5 \\
23 & 204.7 & 197.3 & 207.3 & 209.7 \\
24 & -- & -- & 170.0 & -- \\
25 & -- & -- & 20.7 & -- \\
$2^{\prime}$ & 125.8 & 124.2 & 125.5 & 110.0 \\
$3^{\prime}$ & 108.0 & 109.8 & 107.9 & 127.1 \\
$3 a^{\prime}$ & 127.8 & 127.9 & 127.9 & 118.1 \\
$4^{\prime}$ & 118.2 & 118.5 & 118.4 & 118.5 \\
$5^{\prime}$ & 118.9 & 118.7 & 118.8 & 121.0 \\
$6^{\prime}$ & 121.1 & 121.2 & 121.0 & 111.5 \\
$7^{\prime}$ & 111.7 & 111.7 & 111.4 & 136.2 \\
$7 \mathrm{a}^{\prime}$ & 136.1 & 136.4 & 135.9 & \\
\hline
\end{tabular}

(a)

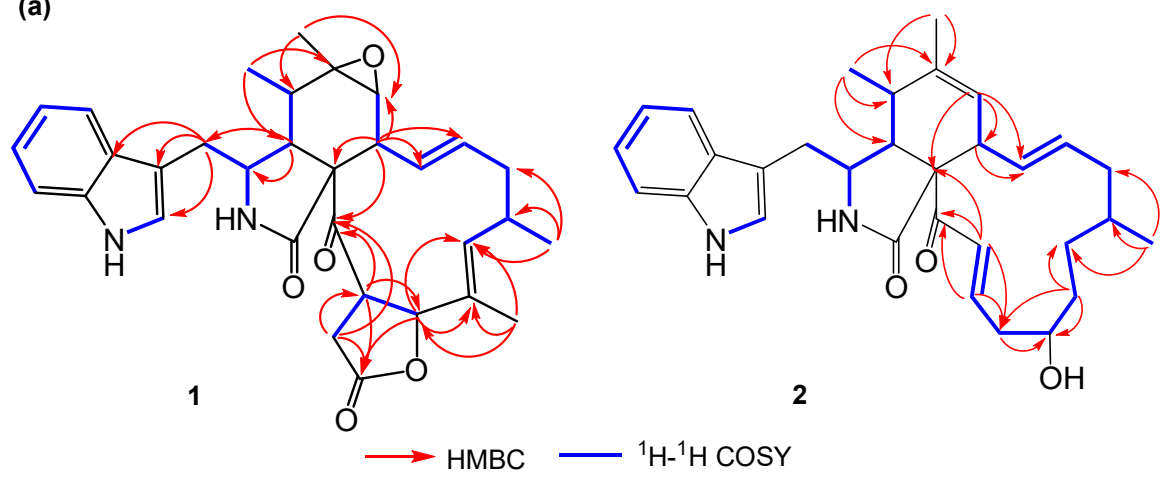

(b)

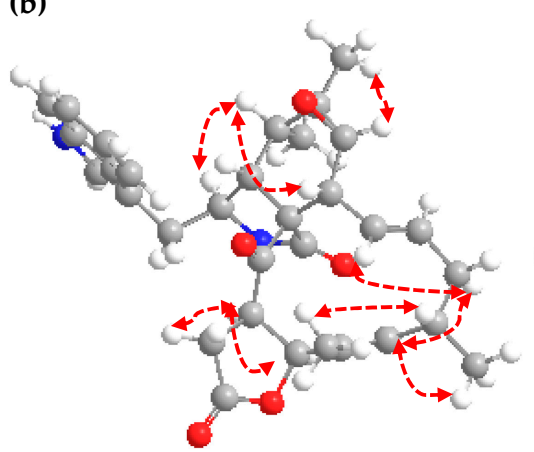

1

(c)

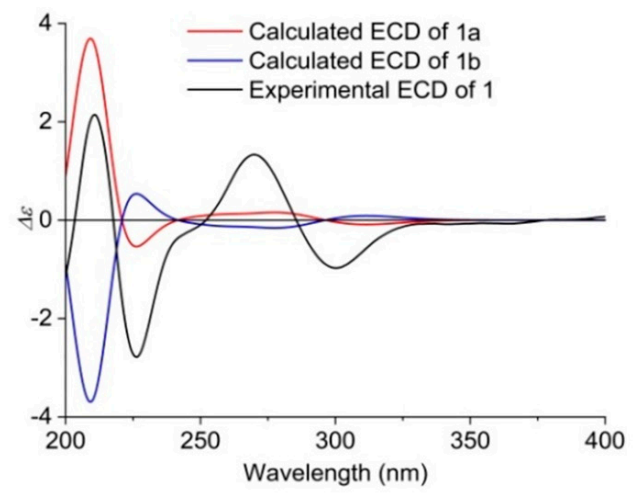

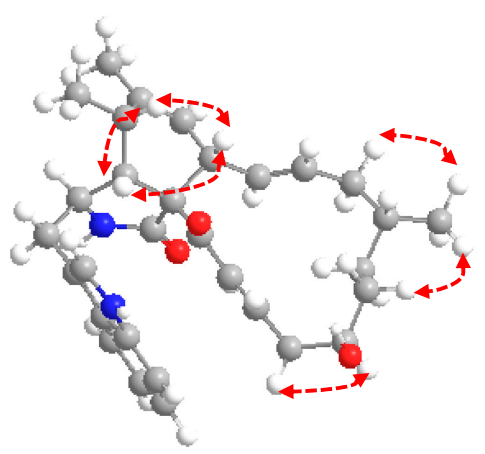

2

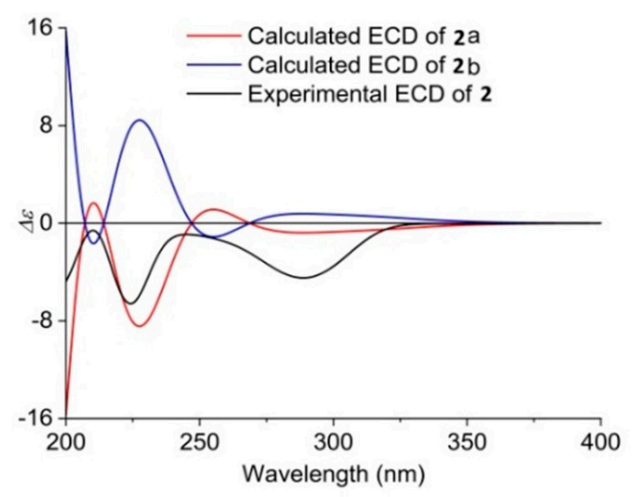

Figure 2. (a) Key HMBC and ${ }^{1} \mathrm{H}-{ }^{1} \mathrm{H}$ COSY correlations of $\mathbf{1}$ and 2 ; (b) Key NOESY correlations of $\mathbf{1}$ and 2; (c) Experimental and calculated ECD of $\mathbf{1}$ and $\mathbf{2}$ (1a, $\mathbf{1 b}$ and 2a, 2b) in $\mathrm{MeOH}$. 


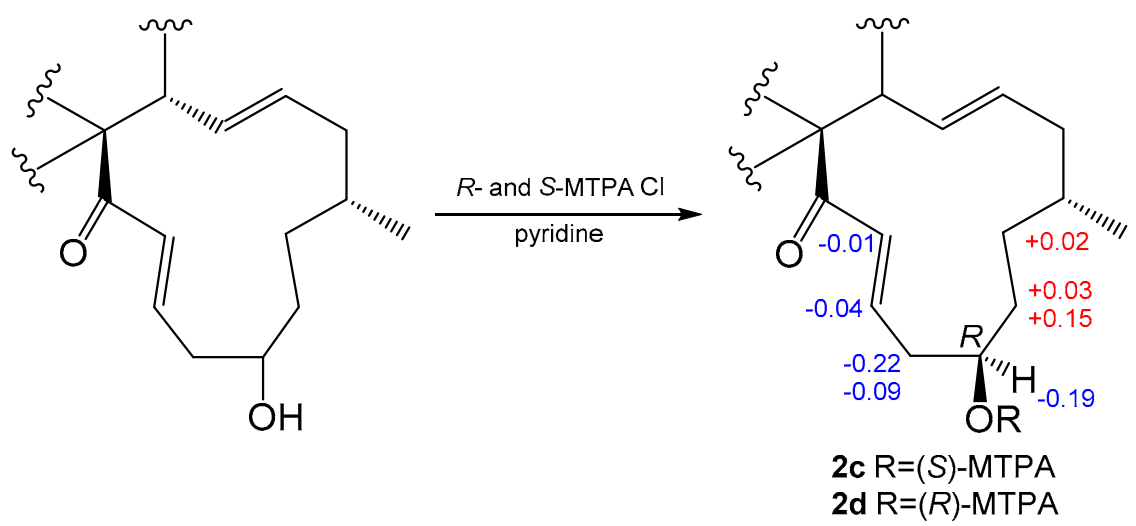

Figure 3. Values of $\Delta \delta_{S}-\delta_{R}$ of the MTPA esters of 2 (in DMSO-d6).

The molecular formula of 3 was determined to be $\mathrm{C}_{34} \mathrm{H}_{40} \mathrm{~N}_{2} \mathrm{O}_{7}$ by HRESIMS, requiring 16 degrees of unsaturation (Tables 1 and 2). The ${ }^{13} \mathrm{C}$ NMR and HSQC spectra of 3 showed the presence of three ketones, two amide or ester groups, five methyls, and two oxygenated carbons. Analysis of the ${ }^{1} \mathrm{H}$ and ${ }^{13} \mathrm{C}-\mathrm{NMR}$ data of 3 indicated that it was similar in structure to compound 7. However, when compared to 7 , the differences were the absence of a pair of double bonds at C-5/C-6, and the presence of a hydroxyl group and a methyl group at C-6 in 3, which was implied by the HMBC correlations from Me-12 to C-5, C-6, and C-7. Additional HMBC correlations from H-7 to C-8, C-9, C-13, C-24, and C-25, as well as from Me-25 to C-24, revealed the presence of an ethoxycarbonyl group at C-7. The NOESY correlations of $\mathrm{H}-8$ with $\mathrm{H}-4$ and $\mathrm{H}-5$ indicated that they had an $\alpha$-orientation, whereas the NOE correlations of $\mathrm{CH}_{3}-12$ with $\mathrm{H}-4$ and $\mathrm{CH}_{3}-11$, as well as $\mathrm{CH}_{3}-11$ with $\mathrm{H}-3$, suggested the configuration of the cyclohexane ring. The absolute configuration of $\mathbf{3}$ was identified by comparing its experimental and calculated ECD data (Figure S30). Thus, 3 was determined as $3 S, 4 R, 5 S, 6 R, 7 S, 8 R, 9 S$ and named phychaetoglobin $C$.

Compound 4 was determined as $\mathrm{C}_{32} \mathrm{H}_{38} \mathrm{~N}_{2} \mathrm{O}_{4}$ on the basis of HR ESIMS. Its NMR data suggested that 4 was an analogue of 8 . However, 4 lacked the hydroxyl group on the cyclopentenone ring that was observed in $\mathbf{8}$. This finding was further confirmed by the HMBC correlations from $\mathrm{CH}_{3}-18$ to C-17 and C-19, as well as from H-19 to C-17, C-20, and $\mathrm{C}-21$. The relative configuration of the five-membered ring from $\mathrm{C}-17$ to $\mathrm{C}-21$ was assigned by the NOESY spectrum. The NOE cross-peaks of $\mathrm{H}-16 / \mathrm{H}-17$ and $\mathrm{CH}_{3}-16 / \mathrm{H}-21$ indicated that the methyl at $\mathrm{C}-16$ and $\mathrm{H}-21$ were in the $\alpha$-orientation, whereas $\mathrm{H}-16$ and $\mathrm{H}-17$ were at the opposite side. The ECD spectrum was determined to confirm the absolute configuration, which was further compared to the experimental spectrum. The ECD spectrum generated for the cyclopentenone ring was $16 S, 17 S, 21 S$, which was consistent with the experimental data of $4 \mathbf{a}$ (Figure S39). Therefore, the absolute configuration was established as in Figure 1 and named phychaetoglobin D.

\subsection{Biological Assay}

Compounds 1-16 were evaluated for their cytotoxicity against HeLa human colon adenocarcinoma cell lines and A549 human lung adenocarcinoma cells by MTT methods (Table 3). Adriamycin was used as a positive control. Compounds 5 and 7 exhibited the strongest cytotoxicity against A549 cell lines, with the $\mathrm{IC}_{50}$ values below $10 \mu \mathrm{M}$. Furthermore, compounds $4-8$ showed a moderate cytotoxicity against HeLa cell lines, with $\mathrm{IC}_{50}$ values of 3.7 10.5 $\mu \mathrm{M}$, implying that the moieties of a double bond at C-5/C-6 and a hydroxyl group at C-7 or an epoxide ring at C-6/C-7 were the characteristics primarily responsible for the cytotoxicity. Compounds $3, \mathbf{1 0}, \mathbf{1 1}$, and 13-16 exhibited cytotoxic activity $\left(\mathrm{IC}_{50}\right.$ values of $\left.12.2 \sim 33.7 \mu \mathrm{M}\right)$, indicating that the presence of a ketone group other than a hydroxyl group at C-20 could increase the bioactivity. However, compound 1 displayed weak activity, which suggested that the lactone ring in $\mathbf{1}$ decreased the cytotoxicity. Compound $\mathbf{2}$ showed weak cytotoxicities, as it did not possess the functional groups related to 
the bioactivity. Thus, the five-membered lactone ring between C-17 and C-21 in $\mathbf{1}$ might decrease the cytotoxicity.

Table 3. Cytotoxicities of Compounds 1--16 against HeLa and A549 cell lines a .

\begin{tabular}{|c|c|c|c|c|c|c|c|c|c|}
\hline \multirow{2}{*}{ Cells } & \multicolumn{9}{|c|}{$\mathrm{IC}_{50}(\mu \mathrm{M})$ Values of Compounds } \\
\hline & 1 & 2 & 3 & 4 & 5 & 6 & 7 & 8 & Adriamycin \\
\hline HeLa & $--b$ & $23.9 \pm 0.4$ & $16.1 \pm 0.3$ & $9.2 \pm 0.3$ & $10.5 \pm 0.1$ & $7.5 \pm 0.2$ & $3.7 \pm 0.3$ & $3.8 \pm 0.3$ & $0.8 \pm 0.3$ \\
\hline \multirow[t]{2}{*}{ A549 } & $32.3 \pm 0.2$ & -- b & $22.3 \pm 0.4$ & $13.7 \pm 0.2$ & $7.6 \pm 0.2$ & $12.3 \pm 0.3$ & $7.3 \pm 0.5$ & $11.0 \pm 0.2$ & $2.9 \pm 0.2$ \\
\hline & 9 & 10 & 11 & 12 & 13 & 14 & 15 & 16 & \\
\hline HeLa & $39.1 \pm 0.5$ & $26.0 \pm 0.4$ & $21.6 \pm 0.2$ & $32.2 \pm 0.2$ & $29.3 \pm 0.2$ & $25.6 \pm 0.2$ & $12.2 \pm 0.1$ & $33.7 \pm 0.3$ & \\
\hline A549 & $--\mathrm{b}$ & $23.2 \pm 0.3$ & $13.4 \pm 0.1$ & $--\mathrm{b}$ & $22.5 \pm 0.3$ & $14.9 \pm 0.2$ & $17.3 \pm 0.3$ & $25.9 \pm 0.2$ & \\
\hline
\end{tabular}

${ }^{\mathrm{a}}$ Adriamycin and DMSO were used as positive and negative controls, and the data were expressed as the means $\pm \operatorname{SD}(n=3) ;{ }^{\mathrm{b}} \mathrm{IC}_{50}$ values were more than $40 \mu \mathrm{M}$.

\section{Materials and Methods}

\subsection{General Experimental Procedures}

Optical rotations were measured with a PerkinElmer 241 polarimeter. NMR spectra were performed on a Bruker ARX-600 spectrometer $(600 \mathrm{MHz}$, Bruker Co., Ltd., Karlsruhe, Germany), and the ${ }^{1} \mathrm{H}$ and ${ }^{13} \mathrm{C}$ NMR chemical shifts were recorded with the solvent peaks for DMSO- $d_{6}\left(\delta_{\mathrm{H}} 2.50\right.$ and $\left.\delta_{\mathrm{C}} 39.50\right)$. High-resolution electrospray ionization mass spectrometry (HRESIMS) data were obtained on a Waters Vion QTOF/MS spectrometer (Waters Mocromass, Manchester, UK) in positive electrospray ionization mode. ECD spectra were recorded on a JASCO J-815 spectrometer (Tokyo, Japan). A UPLC reversed phase C18 analytical column $\left(35^{\circ} \mathrm{C}, 2.1 \mathrm{~mm} \times 100 \mathrm{~mm}, 1.7 \mu \mathrm{m}\right.$, BEH, Waters) was adopted. High performance liquid chromatography (HPLC) was carried out on a Agilent 1260 quaternary system with a UV detector (Agilent, Technologies Co., Ltd., Palo Alto, CA, USA), combined with analytical, semi-preparative or preparative Cosmosil $\mathrm{C}_{18}$-MSII columns $(250 \mathrm{~mm} \times 4.6 \mathrm{~mm}$, and $250 \mathrm{~mm} \times 10 \mathrm{~mm}$ ). Thin-layer chromatography (TLC) was performed with a silica gel plate GF254 (Qingdao Haiyang Chemical Co., Ltd., Qingdao, China). Column chromatography was applied on a Sephadex LH-20 (Pharmacia Fine Chemical Co., Ltd., Uppsala, Sweden), ODS (50 $\mu \mathrm{m}$, YMC Japan) and silica gel (200-300 mesh, Qingdao Haiyang Chemical Ltd., Qingdao, China). Human carcinoma cell lines HeLa and A549 were obtained from the Chinese National Infrastructure of Cell Line Resource (NICR).

\subsection{Fungal Material}

The endophytic fungal KZ-19 was isolated from twigs of the mangrove plant Ceriops tagal, which was collected in Hainan province, China, in July 2013. The plant species was identified by Yi Sun, and the fungus was identified as a Chaetomium globosum by its rRNA gene sequence. The strain was deposited at the institute of Chinese Materia Medica, China Academy of Chinese Medical Sciences.

\subsection{Fermentation and Extraction}

According to the previous investigation of culture conditions, the strain adopted the method of solid fermentation. The strain frozen at $-80^{\circ} \mathrm{C}$ was taken out and cultured on a plate of potato dextrose agar (PDA) medium at $27 \pm 0.5^{\circ} \mathrm{C}$ for 3 days. The mycelium was inoculated aseptically to $500 \mathrm{~mL}$ Erlenmeyer flasks, each containing $40 \mathrm{~g}$ of rice and $60 \mathrm{~mL}$ of distilled water. There were 100 flasks in total, and the flask cultures were incubated at $27 \pm 0.5{ }^{\circ} \mathrm{C}$ for 7 days.

\subsection{Isolation and Purification}

After 7 days, the cultured rice with the fungus was cut into small fragments, which was then subsequently extracted with EtOAc by ultrasonication three times. The solvent was then removed under reduced pressure under vacuum to yield the total extract $(4.7 \mathrm{~g})$. 
The crude extract was fractionated by ODS flash column chromatography $(5 \times 30 \mathrm{~cm})$, eluting with 2L each of $\mathrm{MeOH}-\mathrm{H}_{2} \mathrm{O}(20: 80,40: 60,60: 40,80: 20,100: 0)$. The fraction eluted with $80 \% \mathrm{MeOH}$ was subjected to Sephadex $\mathrm{LH}-20\left(\mathrm{CH}_{2} \mathrm{Cl}_{2}\right.$ : MeOH 1:1) to obtain five subfractions (A-E), and subfraction B was subsequently purified by HPLC (Kromasil Eternity XT-5-C18 column, $250 \times 10 \mathrm{~mm}$ i.d., $5 \mu \mathrm{m}, 2 \mathrm{~mL} \mathrm{~min}^{-1}$ ), with gradient elution from $75 \%$ to $85 \% \mathrm{MeOH}$ in $\mathrm{H}_{2} \mathrm{O}$ with $0.2 \% \mathrm{AcOH}$ to afford compounds $2\left(\mathrm{t}_{\mathrm{R}}=23.0 \mathrm{~min}\right.$, $2.5 \mathrm{mg})$ and $\mathbf{1}\left(\mathrm{t}_{\mathrm{R}}=45.0 \mathrm{~min}, 1.6 \mathrm{mg}\right)$.

The fraction of MeOH- $\mathrm{H}_{2} \mathrm{O}$ (60:40) was chromatographed on Sephadex $\mathrm{LH}-20\left(\mathrm{CH}_{2} \mathrm{Cl}_{2}-\right.$ $\mathrm{MeOH}, 1: 1)$ to yield five subfractions (A-D). Fraction $\mathrm{D}$ was then isolated by silica gel column chromatography (CC) (200-300 mesh), eluting with a $\mathrm{CH}_{2} \mathrm{Cl}_{2}$-acetone gradient system (50:1, 20:1, 10:1, 6:1, 3:1, 2:1, 1:1) to yield five subfractions. The five fractions were analyzed by HPLC, revealing that compounds 3 and 4 were mainly detected in fraction 4.1. Fraction 4.1 was further purified by HPLC $\left(\mathrm{ACN} / \mathrm{H}_{2} \mathrm{O}, 45 \% / 55 \%\right)$, which created compounds 3 ( $2 \mathrm{mg}$ ) and 4 ( $3.5 \mathrm{mg})$.

Compound 1: white solid; $[\alpha]_{\mathrm{D}}^{25}-20.5(c 0.10, \mathrm{MeOH}) ; \mathrm{CD}(\mathrm{MeOH}) 300(\Delta \varepsilon-0.97) \mathrm{nm}$, $270(\Delta \varepsilon+1.33) \mathrm{nm}, 226(\Delta \varepsilon-2.78) \mathrm{nm}, 211(\Delta \varepsilon+2.14) \mathrm{nm} .{ }^{1} \mathrm{H}$ NMR $(600 \mathrm{MHz}$, DMSO-d6) and ${ }^{13} \mathrm{C}$ NMR (150 MHz, DMSO-d6) data (Tables 1 and 2). ESIMS $m / z 471[\mathrm{M}+\mathrm{H}]^{+}$; HR-ESIMS $m / z 528.2670[\mathrm{M}+\mathrm{H}]^{+}$, calcd for $\mathrm{C}_{28} \mathrm{H}_{39} \mathrm{O}_{6}, 528.2625$.

Compound 2: white solid; $[\alpha]_{\mathrm{D}}^{25} 35.6(c 0.10, \mathrm{MeOH}) ; \mathrm{CD}(\mathrm{MeOH}) 224(\Delta \varepsilon-6.59) \mathrm{nm}$, $289(\Delta \varepsilon-4.48) \mathrm{nm} .{ }^{1} \mathrm{H}$ NMR $\left(600 \mathrm{MHz}\right.$, DMSO-d6) and ${ }^{13} \mathrm{C}$ NMR $(150 \mathrm{MHz}$, DMSO-d6) data (Tables 1 and 2). HR-ESIMS $m / z 487.2964[\mathrm{M}+\mathrm{H}]^{+}$, calcd for $\mathrm{C}_{31} \mathrm{H}_{38} \mathrm{~N}_{2} \mathrm{O}_{3}, 487.2966$.

Compound 3: white solid; $[\alpha]_{\mathrm{D}}^{25}-77.1(c 0.10, \mathrm{MeOH}) ; \mathrm{CD}(\mathrm{MeOH}) 225(\Delta \varepsilon-0.74)$ $\mathrm{nm}, 245(\Delta \varepsilon-0.54) \mathrm{nm}, 290(\Delta \varepsilon-0.10) \mathrm{nm} .{ }^{1} \mathrm{H}$ NMR $(600 \mathrm{MHz}, \mathrm{DMSO}-d 6)$ and ${ }^{13} \mathrm{C}$ NMR (150 MHz, DMSO- $d 6$ ) data (Tables 1 and 2). HR-ESIMS $m / z 589.3296[\mathrm{M}+\mathrm{H}]^{+}$, calcd for $\mathrm{C}_{34} \mathrm{H}_{40} \mathrm{~N}_{2} \mathrm{O}_{7}, 589.3321$.

Compound 4: white solid; $[\alpha]_{\mathrm{D}}^{25}-12.5(c$ 0.10, MeOH); CD (MeOH) $219(\Delta \varepsilon+3.97)$ $\mathrm{nm}, 236(\Delta \varepsilon+3.46) \mathrm{nm}, 303(\Delta \varepsilon-0.60) \mathrm{nm} .{ }^{1} \mathrm{H}$ NMR $\left(600 \mathrm{MHz}\right.$, DMSO-d6) and ${ }^{13} \mathrm{C}$ NMR (150 MHz, DMSO-d6) data (Tables 1 and 2). HR-ESIMS $m / z 513.2741[\mathrm{M}+\mathrm{H}]^{+}$, calcd for $\mathrm{C}_{32} \mathrm{H}_{36} \mathrm{~N}_{2} \mathrm{O}_{4}, 513.2748$.

\subsection{Preparation of MTPA Esters of $2 c$ and $2 d$}

Compound $2(200 \mu \mathrm{g}$ for each) was reacted with either $R-(-)-$ or $S-(+)-\mathrm{MTPA} \mathrm{Cl}$ $(5 \mu \mathrm{L})$ in $50 \mu \mathrm{L}$ of $\mathrm{CH}_{2} \mathrm{Cl}_{2}$ and $50 \mu \mathrm{L}$ of pyridine for $2 \mathrm{~h}$. The reaction mixture was diluted with $\mathrm{H}_{2} \mathrm{O}$ and extracted with $\mathrm{CH}_{2} \mathrm{Cl}_{2}$ three times. The organic layers were combined and separated by HPLC (Cosmosil ARII, $10 \times 50 \mathrm{~mm} ; 20-80 \% \mathrm{MeCN}$ in $\mathrm{H}_{2} \mathrm{O}$ ) to afford the $S-(-)$ - or $R$-(+)-MTPA esters, $\mathbf{2 c}$ and $\mathbf{2 d}$.

${ }^{1} \mathrm{H}$ NMR data of $2 \mathrm{c}\left(600 \mathrm{MHz}\right.$ in DMSO-d6): $\delta_{\mathrm{H}} 10.81$ (s, NH-1'), $7.93(\mathrm{~s}, \mathrm{NH}-2), 7.45$ (d, J = 7.8 Hz, H-4'), 7.27 (d, 8.0, H-7'), 7.06 (s, H-2'), 7.02 (m, H-6'), 6.97 (m, H-5'), 6.94 (d, $\mathrm{J}=15.1 \mathrm{~Hz}, \mathrm{H}-22)$, 6.32 (m, H-21), 6.18 (m, H-13), 5.25 (brs, H-7), 5.13 (m, H-14), 3.88 (m, H-19), 3.81 (m H-3), 2.84 (m, H-4), 2.71 (m, H-10a), 2.65 (m, H-8), 2.58 (m, H-10b), 2.27 (m, H-20a), 2.18 (m, H-5), 2.07 (m, H-20b), 2.02 (m, H-16), 1.98 (m, H-15a), 1.64 (m, H-15b), 1.36 (m, H-18a), 1.27 (s, Me-12), 1.20 (m, H-17a), 1.06 (m, H-18b), 0.89 (d, J = 6.7 Hz, Me-16), 0.83 (m, H-17b), 0.80 (d, J = 6.6 Hz, Me-11). HRESI MS: m/z 703.1705 [M+ H] $]^{+}$.

${ }^{1} \mathrm{H}$ NMR data of $2 \mathrm{~d}\left(600 \mathrm{MHz}\right.$ in DMSO-d6): $\delta_{\mathrm{H}} 10.91$ (s, NH-1'), 8.20 (s, NH-2), 7.46(d, $\left.\mathrm{J}=7.6 \mathrm{~Hz}, \mathrm{H}-4^{\prime}\right), 7.27\left(\mathrm{~d}, \mathrm{~J}=7.9 \mathrm{~Hz}, 0, \mathrm{H}-7^{\prime}\right), 7.06\left(\mathrm{~s}, \mathrm{H}-2^{\prime}\right), 7.03$ (m, H-6'), 6.97 (m, H-5'), 6.95 (d, J = 14.9 Hz, H-22), 6.36 (m, H-21), 6.13 (m, H-13), 5.24 (brs, H-7), 5.12 (m, H-14), 4.07 (m, H-19), 3.83 (m H-3), 2.85 (m, H-4), 2.71 (m, H-10a), 2.67 (m, H-8), 2.60 (m, H-10b), 2.49 (m, H-20a), 2.18 (m, H-5), 2.16 (m, H-20b), 2.01 (m, H-16), 1.98 (m, H-15a), 1.64 (m, H-15b), 1.27 (s, Me-12), 1.21 (m, H-18a), 1.18 (m, H-17a), 1.03 (m, H-18b), 0.89 (d, J = 6.7 Hz, Me-16), 0.82 (m, H-17b), $0.80(\mathrm{~d}, \mathrm{~J}=6.6 \mathrm{~Hz}, \mathrm{Me}-11)$. HRESI MS: $\mathrm{m} / \mathrm{z} 703.1738[\mathrm{M}+\mathrm{H}]^{+}$.

\subsection{Computational of ECD}

A conformational search was carried out in the MMFF94 molecular mechanics force field using the MOE software package [22], and all the conformers within an energy window 
of $10 \mathrm{kcal} / \mathrm{mol}$ were regarded as the initial conformations. The geometry optimization and frequency calculations were performed with Gaussian16 RevB.01 [23], using the $\omega$ B97XD or B3LYP functional at the 6-311G(d,p) level of theory to verify the stability and obtain the energies at $298.15 \mathrm{~K}$ and a $1 \mathrm{~atm}$ pressure. The Boltzmann distribution was calculated according to their Gibbs free energies. ECD calculations were conducted by using the Cam-B3LYP functional at the TZVP level of theory. The Solvation Model Based on Density (SMD) was used as the solvation model. The Boltzmann-averaged ECD spectra were obtained by using SpecDis 1.71 software [24].

\subsection{Cytotoxicity Assay}

The cytotoxic activities of 1-16 against human carcinoma cells HeLa and A549 were determined using the 3-(4,5-dimethyl-2-thiazolyl)-2,5-diphenyl-2-H-tetrazolium bromide (MTT) assay. The cells were maintained in RPMI-1640 containing 10\% (v/v) fetal bovine serum (FBS) and $0.4 \%(v / v)$ penicillin-streptomycin solution $(10,000 \mathrm{units} / \mathrm{mL}$ penicillin and $10,000 \mu \mathrm{g} / \mathrm{mL}$ streptomycin, $100 \times$ ) at $37^{\circ} \mathrm{C}$ under $5 \% \mathrm{CO}_{2}$. The cells were digested by trypsinization and then diluted to a concentration of $1 \times 10^{4}$ cells $/ \mathrm{mL}$. The diluted cell suspensions were then placed into 96-well microtiter plates and incubated with the test samples for $72 \mathrm{~h}$. The control contained $2 \mu \mathrm{L} \mathrm{MeOH}$. After incubation, the MTT solution was added and plates were incubated for $4 \mathrm{~h}$. The supernatant liquid was removed, and the cells were disrupted with $150 \mu \mathrm{L}$ DMSO for $10 \mathrm{~min}$. The absorption was measured at $570 \mathrm{~nm}$.

\section{Conclusions}

Four new cytochalasans, phychaetoglobins A-D (1-4), together with twelve known cytochalasans (5-16), were identified from the culture of C. globosum kz-19. All cytochalasans were tested for their cytotoxicities against HeLa and A549 tumor cell lines. Among compounds 4-8, those that contained a C-5/C-6 double bond and a C-7 hydroxyl group or a C-6/C-7 epoxide ring exhibited strong cytotoxic activities with the $\mathrm{IC}_{50}$ values of 3.7-13.7 $\mu \mathrm{M}$. Compound 1 represents the first example of a cytochalasan with a fivemembered lactone fused in the macrocyclic ring. Natural cytochalasans containing a cyclopentenone or a pyrrole moiety in the macrocyclic ring are rare. To our knowledge, only four natural cytochalasans containing a cyclopentenone ring have been reported, including cytoglobosin A [4], chaetoglobosin U [25], V [17], and Vb [26]. Furthermore, 11 pyrrole-containing cytochalasans are penochalasins A1-C3 [27] and armochaetoglobosins K-R [28]. Therefore, this study diversifies the structures of natural cytochalasans.

Supplementary Materials: The following are available online at https:/ / www.mdpi.com/article/10.3 390/md19080438/s1, Figures S1-S63: The HRESIMS, 1 D, 2D NMR, and CD spectra of compounds 1-16.

Author Contributions: Validation, T.L., Y.W., M.T. and Q.M.; formal analysis, Y.S. and L.L.; investigation, Y.S.; data curation, T.L. and C.Z.; writing-original draft preparation, T.L.; writing-review and editing, Y.S.; supervision, Y.P. and E.H.; All authors have read and agreed to the published version of the manuscript.

Funding: This work was supported in part by the National Key Research and Development Program of China (2018YFC1706104), and the National Natural Science Foundation of China (81502968).

Conflicts of Interest: The authors declare no conflict of interest.

\section{References}

1. Scheriach, K.; Boettger, D.; Remme, N.; Hertweck, C. The chemistry and biology cytochalasans. Nat. Prod. Rep. 2010, 27, 869-886. [CrossRef] [PubMed]

2. Qi, J.; Jiang, L.; Zhao, P.; Chen, H.; Jia, X.; Zhao, L.; Dai, H.; Hu, J.; Liu, C.; Shim, S.H.; et al. Chaetoglobosins and azaphilones from Chaetomium globosum associated with Apostichopus japonicus. Appl. Microbiol. Biotechnol. 2020, 104, 1545-1553. [CrossRef] [PubMed] 
3. Selim, K.A.; Ei-Beih, A.A.; Abdel-Rahman, T.M.; Ei-Diwany, A.I. Biological evaluation of endophytic fungus, Chaetomium globosum JN711454, as potential candidate for improving drug discovery. Cell Biochem. Biophys. 2014, 68, 67-82. [CrossRef] [PubMed]

4. Cui, C.M.; Li, X.M.; Li, C.S.; Proksch, P.; Wang, B.G. Cytoglobosins A-G, cytochalasans from a marine-derived endophytic gungus, Chaetomium globosum QEN-14. J. Nat. Prod. 2010, 73, 729-733. [CrossRef]

5. Chen, C.; Wang, J.; Liu, J.; Zhu, H.; Sun, B.; Wang, J.; Zhang, J.; Luo, Z.; Yao, G.; Xue, Y.; et al. Armochaetoglobins A-J: Cytochalasan alkaloids from Chaetomium globosum TW1-1, a fungus derived from the tereestrial arthropod Armadillidium vulgare. J. Nat. Prod. 2015, 78, 1193-1201. [CrossRef]

6. Trendowski, M. Using cytochalasins to improve current chemotherapeutic approaches. Anticancer Agents Med. Chem. 2015, 15, 327-335. [CrossRef]

7. Gao, X.; He, Y.; Chai, C.; Zhang, J.; Guo, J.; Chen, C.; Wang, J.; Zhu, H.; Hu, Z.; Zhang, Y. Antibacterial activity against drug-resistant microbial pathogens of cytochalasan alkaloids from the arthropod-associated fungus Chaetomium globosum TW1-1. Bioorg. Chem. 2019, 83, 98-104. [CrossRef]

8. Gong, W.; Gong, J.; Liu, X.; Dai, C.; Wang, Y.; Li, X.N.; Wang, J.; Luo, Z.; Zhou, Y.; Xue, Y.; et al. Cytochalasans produced by the coculture of Aspergillus flavipes and Chaetomium globosum. J. Nat. Prod. 2018, 81, 1578-1587.

9. Li, H.; Wei, H.; Hu, J.; Lacey, E.; Sobolev, A.N.; Stubbs, K.A.; Solomon, P.S.; Chooi, Y.H. Genomics-driven discovery of phytotoxic cytochalasans involved in the virulence of the wheat pathogen Parrastagonospora nodorum. ACS Chem. Biol. 2020, 15, $226-233$. [CrossRef]

10. Schumann, J.; Hertweck, C. Molecular basis of cytochalasan biosynthesis in fungi: Gene cluster analysis and evidence for the involvement of a PKS-NRPS hybrid synthase by RNA silencing. J. Am. Chem. Soc. 2007, 129, 9564-9565. [CrossRef]

11. Skellam, E. The biosynthesis of cytochalasans. Nat. Prod. Rep. 2017, 34, 1252-1263. [CrossRef]

12. Trendowski, M. Recent advances in the development of antineoplastic agents derived from natural products. Drugs 2015, 75, 1993-2016. [CrossRef] [PubMed]

13. Zhu, H.; Chen, C.; Tong, Q.; Zhou, Y.; Ye, Y.; Gu, L.; Zhang, Y. Progress in the chemistry of cytochalasans. Prog. Chem. Org. Nat. Prod. 2021, 114, 1-134. [PubMed]

14. Liu, Z.; Sun, Y.; Tang, M.; Sun, P.; Wang, A.; Hao, Y.; Wang, Y.; Pei, Y. Trichodestruxins A-D: Cytotoxic cyclodepsipeptides from the endophytic fungus Trichoderma harzianum. J. Nat. Prod. 2020, 83, 3635-3641. [CrossRef] [PubMed]

15. Sekita, S.; Yoshihira, K.; Natori, S. Chaetoglobosins, cytotxic 10-(Indol-3-yl)-[13] cytochalasans from Chaetomium spp.IV. ${ }^{13}$ Cnuclear magnetic resonance spectra and their application to a biosynthetic study. Chem. Pharm. Bull. 1982, 31, 490-498. [CrossRef]

16. Sekita, S.; Yoshihira, K.; Natori, S.; Kuwano, H. Chaetoglobosins, Cytotoxic 10-(Indol-3-yl)-[13] cytochalasans from Chaetomium spp. III. Structures of Chaetoglobosins C, E, F, G, and J. Chem. Pharm. Bull. 1982, 30, 1629-1638. [CrossRef]

17. Zhang, J.; Ge, H.; Jiao, R.H.; Li, J.; Peng, H.; Wang, Y.R.; Wu, J.H.; Song, Y.C.; Tan, R.X. Cytotoxic chaetoglobosins from the endophyte Chaetomium globosum. Planta Med. 2010, 76, 1910-1914. [CrossRef]

18. Sekita, S.; Yoshihira, K.; Natori, S.; Kuwano, H. Chaetoglobosins G and J, cytotoxic indol-3-yl [13]-cytochalasans from Chaetomium globogum. Tetrahedron Lett. 1977, 32, 2771-2774. [CrossRef]

19. Iwamoto, C.; Yamada, T.; Ito, Y.; Minoura, K.; Numata, A. Cytotoxic cytochalasans from a Penicillium species separated from a Marine alga. Tetrahedron 2001, 57, 2997-3004. [CrossRef]

20. Huang, S.; Chen, H.; Li, W.; Zhu, X.; Ding, W.; Li, C. Bioactive Chaetoglobosins from the Mangrove Endophytic Fungus Penicillium chrysogenum. Mar. Drugs 2016, 14, 172. [CrossRef]

21. Oikawa, H.; Murakami, Y.; Ichihara, A. Useful approach to find the plausible biosynthetic precursors of secondary metabolites using p-450 inhibitors: Postulated intermediates of Chaetoglobosin, A.J. Chem. Soc. Perkin Trans. 1 1992, 2949-2953. [CrossRef]

22. MOE2009.10. Chemical Computing Group Inc. Available online: https://www.chemcomp.com/Products.htm (accessed on 31 July 2021).

23. Frisch, M.J.; Trucks, G.W.; Schlegel, H.B.; Scuseria, G.E.; Robb, M.A.; Cheeseman, J.R.; Scalmani, G.; Barone, V.; Petersson, G.A.; Nakatsuji, H.; et al. Gaussian 16, Revision B.01; Gaussian, Inc.: Wallingford, CT, USA, 2016.

24. Bruhn, T.; Schaumlöffel, A.; Hemberger, Y.; Pescitelli, G. SpecDis Version 1.71. Berlin, Germany. 2017. Available online: https:/ specdis-software.jimdo.com (accessed on 12 July 2021).

25. Ding, G.; Song, Y.C.; Chen, J.R.; Xu, C.; Ge, H.M.; Wang, X.T.; Tan, R.X. Chaetoglobosin U, a cytochalasan alkaloid from endophytic Chaetomium globosum IFB-E019. J. Nat. Prod. 2006, 69, 302-304. [CrossRef] [PubMed]

26. Xue, M.; Zhang, Q.; Gao, J.M.; Li, H.; Tian, J.M.; Pescitelli, G. Chaetoglobosin Vb from endophytic Chaetomium globosum: Absolute configuration of chaetoglobosins. Chirality 2012, 24, 668-674. [CrossRef] [PubMed]

27. Numata, A.; Takahashi, C.; Ito, Y.; Minoura, K.; Yamada, T.; Matsuda, C.; Nomoto, K. Penochalasins, a novel class of cytotoxic cytochalasans from a Penicillium species separated from a marine alga. J. Chem. Soc. Perkin Trans. 1 1996, 1, 239-245. [CrossRef]

28. Chen, C.; Zhu, H.; Wang, J.; Yang, J.; Li, X.; Wang, J.; Chen, K.; Wang, Y.; Luo, Z.; Yao, G.; et al. Armochaetoglobins K-R, anti-HIV pyrrole-based cytochalasans from Chaetomium globosum TW1-1. Eur. J. Org. Chem. 2015, 3086-3094. [CrossRef] 